\title{
FORMULATION AND EVALUATION OF DELAYED-RELEASE TABLETS OF PALIPERIDONE
}

\author{
Goski Vijendhar *, C. Swethaa and K. Mohini \\ Chilkur Balaji College of Pharmacy, Aziznagar Post Moinabad Road, Hyderabad - 500075, Andhra \\ Pradesh, India.
}

\begin{abstract}
Paliperidone is a well-known dopamine antagonist of the atypical antipsychotic class. The present research work was an attempt to formulate and evaluate paliperidone delayed-release tablets. A combination of hydroxypropyl methylcellulose (HPMC K100M) and polyvinyl acetate phthalate, cellulose acetate phthalate were used as polymers. The tablets were prepared by direct compression method. 12 formulations were prepared by changing the ratios of the drug and polymer to study the effect of variable concentrations of polymers and characteristics of the tablets. The prepared tablets were evaluated by different parameters such as Thickness, weight variation, hardness, content uniformity. The tablets were also evaluated for in vitro drug release in $0.1 \mathrm{~N} \mathrm{HCl}$ for $12 \mathrm{~h}$ in USP Type II dissolution apparatus. Among all the formulations (F-I to F-XII) prepared, batch F-12 gave good results of Paliperidone when compared to other formulations. Hence, formulation F12 was found to be equivalent to a marketed product with good bioavailability properties. It also showed no significant change in physical appearance and drug content.
\end{abstract}

Keywords: Dopamine antagonist, Atypical antipsychotic class, HPMC K100M, Cellulose, Acetate phthalate, Polyvinyl acetate phthalate, FTIR studies

\section{Correspondence to Author: \\ Goski Vijendhar}

Chilkur Balaji College of Pharmacy, Aziznagar Post Moinabad Road, Hyderabad - 500075, Andhra Pradesh, India.

E-mail: vijendar16@gmail.com

INTRODUCTION: The oral administration of drugs represents the most common way of drug application due to its high patient acceptance. The immediate release of drug delivery systems is particularly used to produce fast therapeutic drug plasma levels. This results in reduction or loss in drug effectiveness or also increased the incidence of side effects. Modified release drug delivery systems include the systems with $\mathrm{pH}$ dependent, extended, delayed, or pulsed drug release ${ }^{1-5}$.

\begin{tabular}{|l|c|}
\hline QUICK RESPONSE CODE & DOI: \\
\hline DOI link: http://dx.doi.org/10.13040/IJPSR.0975-8232.IJLSR.1(2).48-64 \\
\hline
\end{tabular}

Sustained, extended or prolonged release drug delivery devices, by contrast, are delayed release dosage forms have to be distinguished from the ones mentioned as they exhibit a more or less pronounced lag time before drug release ${ }^{6}$.

A delayed-release dosage form is designed to release the drug at a time other than promptly after administration. Dosage forms can be designed to modify the release of the drug over a given time or after the dosage form reaches the required location. To overcome the disadvantages of conventional release dosage forms, the formulations can be modified to provide either delayed release or extended release of drugs. A delayed-release dosage form is designed to release the drug at a time other than promptly after administration. Dosage forms can be designed to modify the 
release of the drug over a given time or after the dosage form reaches the required location. Delayed Release oral dosage forms can control where the drug is released, e.g., when the dosage form reaches the small intestine (enteric-coated dosage forms) or the colon (colon-specific dosage forms). Delayed Release systems release a bolus of the drug after a predetermined time in a predetermined location, i.e., they do not release the drug immediately after ingestion, for example, entericcoated tablets, pulsatile-release capsules.
Paliperidone is the primary active metabolite of the older antipsychotic risperidone. While its specific mechanism of action is unknown, it is believed paliperidone and risperidone act via similar, if not identical, pathways. Paliperidone has antagonist effect at $\alpha_{1}$ and $\alpha_{2}$ adrenergic receptors and $\mathrm{H}_{1}$ histamine receptors. It does not bind to muscarinic acetylcholine receptors. Also, it binds with dopamine and serotonin receptors. Paliperidone has more affinity D4 receptors than risperidone ${ }^{7-14}$.

\section{MATERIALS AND METHODS:}

TABLE 1: LIST OF MATERIALS

\begin{tabular}{cccc}
\hline S. no. & Material Name & Monograph Ref. & Functional Category \\
\hline 1 & Paliperidone & IH & Active \\
2 & Microcrystalline cellulose & USP & Diluent \\
3 & Sodium starch glycolate & NF & Disintegrant \\
4 & Sodium carbonate anhydrous & USP & Stabilizer \\
& Lubrication & NF & Lubricant \\
5 & Sodium stearyl fumarate & & \\
& Seal coating & $\mathrm{NF}$ & Seal coat former \\
6 & Ethyl cellulose & $\mathrm{NF}$ & Channeling agent \\
7 & Water insoluble polymer (Compound A) & $\mathrm{NF}$ & Channeling agent \\
8 & Water soluble polymer (Compound B) & USP & Solvent \\
9 & Dehydrated alcohol\# & & \\
& Enteric coating & NF & Enteric polymer \\
10 & HPMC K 100M & USP & Plasticizer \\
11 & Diacetylated monoglycerides & Colorant \\
12 & Pigment blend -Yellow powder & USP & Solvent \\
13 & Dehydrated alcohol\# & SSP & Solvent \\
14 & Purified Water \# &
\end{tabular}

TABLE 2: LIST OF TYPES OF EQUIPMENT

\begin{tabular}{cccc}
\hline S. no. & Equipment & Manufacturer & Model No. \\
\hline 1 & Electronic Balance & Shimadzu & AUX220 \\
2 & Sieves & United Engineering Ltd. & ASL00 \\
3 & Tab density Tester & Electrolab & ETD-020 \\
4 & Electromagnetic Sieve Shaker & Electropharma & EMS- 8 \\
5 & Double Cone bin & United Eng. & Double Cone \\
6 & Laboratory Stirrer & Remi & RQT-124A \\
7 & Automatic Coating System & Nano machines & Neocota 5T \\
8 & Rapid dryer & Retsch & TG-200 \\
9 & pH Meter & Thermo & Orion 2 Star \\
10 & Dissolution test apparatus & Electro lab USP XXII & TDT-08L \\
11 & Stability chambers & Thermo lab & Standard \\
12 & Disintegration Tester & Electrolab & ED-2L \\
13 & Hardness tester & Pharmatest & PTB-311E \\
14 & Friabilator & Electrolab & EF-1W \\
15 & Tablet Compression machine-16 Station & Cadmech Machinery co. Pvt.Ltd & CM D3-16 \\
16 & Induction Cap Sealer & Electronic Devices & Sigma Jr.(CSP 300) \\
17 & Peristaltic pump & Electrolab & PP-50V \\
18 & Homogenizer & Chamunda pharma machinery pvt. Ltd. & CPM-HO \\
19 & Dehumidifier & Bry air Asia Pvt. Ltd. & FFB-300 \\
\hline
\end{tabular}


Preformulation Study: Preformulation testing was an investigation of physical and chemical properties of a drug substance alone and when combined with excipients. It was the first step in the rational development of dosage forms ${ }^{15}$.

Objective / Purpose of Preformulation Study: ${ }^{16-}$ ${ }^{19}$ Pre-formulation studies on active pharmaceutical ingredients (API), inactive ingredients (Excipients), and their combinations were carried out to serve the following purposes:

$\checkmark$ To finalize specifications of active pharmaceutical ingredients (API)

$\checkmark$ To study the compatibility between active and inactive ingredient

$\checkmark$ Characterization of the reference product.

Scope: The use of preformulation parameters maximizes the chances in formulating an acceptable, safe, efficacious, and stable product.

Class: The preformulation study can be divided into two subclasses:

1. API characterization,

2. Compatibility study

\section{Active Pharmaceutical Ingredient (API) Characterization:}

Organoleptic Evaluation: These are preliminary characteristics of any substance which is useful in the identification of specific material. Following physical properties of API were studied.

\begin{tabular}{lc}
$\begin{array}{l}\text { Color } \\
\text { - Odour } \\
\text { Taste }\end{array}$ & \\
\hline Parameter & Paliperidone \\
\hline Evaluation & White to slightly yellowish- \\
white solid \\
Very soluble in water, \\
Solubility Analysis \\
Very soluble in methanol, \\
Freely soluble in ethanol, \\
chloroform, and ethyl acetate, \\
insoluble in ether and n-hexane.
\end{tabular}

Loss on Drying: $0.5 \mathrm{~g}$ of a sample of Paliperidone was accurately weighed, and the powder was kept in a moisture balance apparatus for $5 \mathrm{~min}$. at $106^{\circ} \mathrm{Cand}$ the moisture content was calculated.
Bulk Density: Bulk density was determined by pouring $15.3 \mathrm{gm}$ of the sample (paliperidone) through a glass funnel into $50 \mathrm{ml}$ graduated cylinder. The volumes occupied by the samples were recorded. Bulk density was calculated as:

Bulk density = Weight of sample in gm / Volume occupied by the sample

Tapped Density: Tapped density was determined by using Electro lab density tester, which consists of a graduated cylinder mounted on a mechanical tapping device. An accurately weighed sample of powder was carefully added to the cylinder with the aid of a funnel. Typically, the initial volume was noted, and the sample is then tapped $(500,750$ or 1250 tapping) until no further reduction in volume is noted or the percentage of difference is not more than $2 \%$. A sufficient number of taps should be employed to assure reproducibility for the material in question. Volume was noted, and taped density is calculated using the following formula.

Compressibility Index and Hausner ratio: In recent years the compressibility index and the closely related Hausner ratio have become the simple, fast, and popular methods of predicting powder flow characteristics. Both the compressibility index and the Hausner's ratio were determined by using bulk density and the tapped density of a powder.

Carr's index $=$ Tapped density - Bulk density / Tapped density $\times 100$

Hauser's ratio $=$ Tapped density / Bulk density

TABLE 3: RELATION OF FLOW PROPERTY WITH HR \& CI

\begin{tabular}{ccc}
\hline $\begin{array}{c}\text { Compressibility } \\
\text { Index }(\%)\end{array}$ & $\begin{array}{c}\text { Flow } \\
\text { Character }\end{array}$ & $\begin{array}{c}\text { Hauser's } \\
\text { Ratio }\end{array}$ \\
\hline$<10$ & Excellent & $1.00-1.11$ \\
$11-15$ & Good & $1.12-1.18$ \\
$16-20$ & Fair & $1.19-1.25$ \\
$21-25$ & Passable & $1.26-1.34$ \\
$26-31$ & Poor & $1.35-1.45$ \\
$32-37$ & Very poor & $1.46-1.59$ \\
$>38$ & Very, very poor & $>1.60$ \\
\hline
\end{tabular}

\section{Calculation of BD, TD, CI, \& HR of API: For Paliperidone:}

The initial weight of API taken $=14.6 \mathrm{gm}$

The initial volume of API taken $=28 \mathrm{ml}$

Volume after 500 tap $\quad=20 \mathrm{ml}$

Volume after 750 tap $\quad=19 \mathrm{ml}$ 
TABLE 4: CALCULATION OF BD, TD, CI, \& HR OF API

\begin{tabular}{ccc}
\hline Parameter & Value & Unit \\
\hline LOD & 1.0 & $\% \mathrm{w} / \mathrm{w}$ \\
BD & 0.5214 & $\mathrm{gm} / \mathrm{ml}$ \\
TD & 0.7684 & $\mathrm{gm} / \mathrm{ml}$ \\
CI & 32.140 & $\%$ \\
HR & 01.473 & --- \\
\hline
\end{tabular}

The Angle of Repose: (USP29-NF-24): The angle of repose has been used to characterize the flow properties of solids. The angle of repose is a characteristic related to inter particulate friction or resistance to movement between particles. This is the maximum angle possible between the surface of the pile of powder or granules and the horizontal plane.

$$
\operatorname{Tan} \theta=\mathrm{h} / \mathrm{r} \text { or } \theta=\operatorname{Tan}^{-1} \mathrm{~h} / \mathrm{r}
$$

Where, $\theta=$ angle of repose, $\mathrm{h}=$ height, $\mathrm{r}=$ radius.

A funnel was fixed at a height approximately of 2-4 $\mathrm{cm}$ over the platform. The loose powder was slowly passed along the wall of funnel, till the cone of the powder formed. Determine the angle of repose by measuring the height of the cone of powder and radius of the heap of powder.

TABLE 5: FLOW PROPERTIES AND CORRESPONDING ANGLES OF REPOSE

\begin{tabular}{cc}
\hline $\begin{array}{c}\text { Flow } \\
\text { Property }\end{array}$ & $\begin{array}{c}\text { The angle of Repose } \\
\text { (degrees) }\end{array}$ \\
\hline Excellent & $25-30$ \\
Good & $31-35$ \\
Fair - aid not needed & $36-40$ \\
Passable - may hang up & $41-45$ \\
Poor - must agitate, vibrate & $46-55$ \\
Very poor & $56-65$ \\
Very, very poor & $>66$ \\
\hline
\end{tabular}

Sieve Analysis: The procedure involves the Electromagnetic Sieve shaking of the sample through the series of successively arranged sieves (sieve no. - 20, 30, 40, 60, 80, and receiver), and weighing of the portion of the sample retained on each sieve and calculate percentage retained on each sieve.

\section{Compatibility Studies: ${ }^{20-24}$}

Drug-Excipient Compatibility Studies: The compatibility of drug and formulation components is important prerequisite before formulation. It is, therefore, necessary to confirm that the drug does not react with the polymers and excipients under experimental conditions and affect the shelf life of the product or any other unwanted effects on the formulation.

Procedure: The drug is mixed with excipients in a different ratio. These mixtures were kept in a $5 \mathrm{ml}$ glass white colored vials and packed properly. These vials are exposed to 1) room temperature 2) 2-8 ${ }^{\circ} \mathrm{C}$ and 3) $40{ }^{\circ} \mathrm{C} / 75 \% \mathrm{RH} .15 \mathrm{gm}$ of the blend is prepared, which is filled in 3 vials. Observations for physical appearance are made at zero weeks, 2 weeks, and 4week, the samples were withdrawn for analysis of the following parameter:

1. Moisture content

2. Assay

3. Related substance

4. Appearance.

\section{Formulation Development: ${ }^{25-31}$}

Formulation Development of Paliperidone Enteric Coated Tablets: Based on Preformulation data, various excipients were selected, and their compilation was shown in the below table.

\section{TABLE 6A: COMPILATION OF PALIPERIDONE ENTERIC COATED TABLETS}

\begin{tabular}{|c|c|c|c|c|c|c|c|}
\hline \multirow{2}{*}{$\begin{array}{c}\text { S. } \\
\text { no. }\end{array}$} & \multirow[t]{2}{*}{ Ingredients } & \multicolumn{6}{|c|}{$\mathrm{mg} / \mathrm{tab}$} \\
\hline & & F 1 & F 2 & F 3 & F 4 & F 5 & F 6 \\
\hline 1 & Paliperidone sodium (API) & 20 & 20 & 20 & 20 & 20 & 20 \\
\hline 2 & Microcrystalline cellulose (Diluent) & 52.20 & 52.20 & 66.30 & 66.30 & 40.30 & 40.30 \\
\hline 3 & Sodium carbonate anhydrous (Stabilizer) & 10 & 10 & 10 & 10 & 10 & 10 \\
\hline 4 & Sodium starch glycolate (Disintigrent) & 33.80 & 33.80 & 23 & 23 & 44 & 44 \\
\hline 5 & Hydroxy propyl cellulose (Binder) & 2.50 & 2.50 & - & - & 5.00 & 5.00 \\
\hline 6 & Sodium steryl fumarate (Lubricant) & 2.70 & 2.70 & 2.70 & 2.70 & 2.70 & 2.70 \\
\hline \multicolumn{8}{|c|}{ Seal Coating Stage } \\
\hline 7 & Ethyl cellulose & 1.62 & 2.16 & 2.7 & 4.05 & 2.7 & 4.05 \\
\hline 8 & Water insoluble polymer (compound A) & - & - & 2.7 & 4.05 & 2.7 & 4.05 \\
\hline 9 & Water soluble polymer (compound B) & 6.48 & 8.64 & - & - & - & - \\
\hline 10 & Ethanol & q.s & q.s & q.s & q.s & q.s & q.s \\
\hline \multicolumn{8}{|c|}{ Enteric coating stage } \\
\hline 11 & HPMC K 100 M & 17.17 & 17.50 & 16.85 & 17.17 & 16.85 & 17.17 \\
\hline 12 & Myvacet & 1.72 & 1.75 & 1.69 & 1.72 & 1.69 & 1.72 \\
\hline 13 & Pigment blend Yellow & 2.58 & 2.62 & 2.52 & 2.58 & 2.52 & 2.58 \\
\hline
\end{tabular}


TABLE 6B: COMPILATION OF PALIPERIDONE ENTERIC COATED TABLETS

\begin{tabular}{|c|c|c|c|c|c|c|c|}
\hline \multirow{2}{*}{$\begin{array}{l}\text { S. } \\
\text { no. }\end{array}$} & \multirow[t]{2}{*}{ Ingredients } & \multicolumn{6}{|c|}{$\mathrm{mg} / \mathrm{tab}$} \\
\hline & & F 1 & F 2 & F 3 & F 4 & F 5 & F 6 \\
\hline 1 & Paliperidone & 20 & 20 & 20 & 20 & 20 & 20 \\
\hline 2 & Microcrstalline cellulose & 60.30 & 60.30 & 52.80 & 52.80 & 45.30 & 45.30 \\
\hline 3 & Sodium Carbonate Anhydrous & 10 & 10 & 10 & 10 & 10 & 10 \\
\hline 4 & Sodium starch glycolate & 24 & 24 & 34 & 34 & 44 & 44 \\
\hline 5 & Hydroxy propyl cellulose & 5.00 & 5.00 & 2.50 & 2.50 & - & - \\
\hline 6 & Sodium starch Fumarate & 2.70 & 2.70 & 2.70 & 2.70 & 2.70 & 2.70 \\
\hline \multicolumn{8}{|c|}{ Seal Coating Stage } \\
\hline 7 & Ethyl Cellulose & 2.7 & 4.05 & 2.7 & 4.05 & 2.7 & 4.05 \\
\hline 8 & Water Insoluble Polymer (Compound A) & 2.7 & 4.05 & 2.7 & 4.05 & 2.7 & 4.05 \\
\hline 9 & Water soluble polymer (compound B) & - & - & - & - & - & - \\
\hline 10 & Ethanol & q.s & q.s & q.s & q.s & q.s & q.s \\
\hline \multicolumn{8}{|c|}{ Enteric coating stage } \\
\hline 11 & HPMC K 100M & 16.85 & 17.17 & 16.85 & 17.17 & 16.85 & 17.17 \\
\hline 12 & Myvacet (emulsifier lubricant anti foaming agent) & 1.69 & 1.72 & 1.69 & 1.72 & 1.69 & 1.72 \\
\hline 13 & Pigment blend Yellow (colouring agent refinishing coating) & 2.52 & 2.58 & 2.52 & 2.58 & 2.52 & 2.58 \\
\hline 14 & Ethanol & q.s & q.s & q.s & q.s & q.s & q.s \\
\hline
\end{tabular}

In the preparation of enteric coating dispersion the ratio of ethanol: purified water used is 80:20.The strength of both seal coating and enteric coatings is $10 \% \mathrm{w} / \mathrm{w}$.

\section{Formulation Batches:}

F1: In the first trial F1, $20 \mathrm{mg}$ of API, $10 \mathrm{mg}$ of stabilizer, $52.20 \mathrm{mg}$ of diluent, $33.80 \mathrm{mg}$ of disintegrant, $2.50 \mathrm{mg}$ of HPC, $2.7 \mathrm{mg}$ of lubricant was used, and the blend was compressed into tablets. On that seal coating was given by using 20:80 of ethyl cellulose: water-soluble compound (compound C) up to a weight build-up of $6 \% \mathrm{w} / \mathrm{w}$ and on that $15 \% \mathrm{w} / \mathrm{w}$ of the enteric coating was given.

F2: In formulation $\mathrm{F} 2$, the core is same as that of $\mathrm{F} 1$, and the seal coating material is also same but the seal coat is given up to weight build-up of $8 \% \mathrm{w} / \mathrm{w}$ and on that $15 \% \mathrm{w} / \mathrm{w}$ of the enteric coating was given.

F3: In formulation F3, then amounts of API, stabilizer, lubricant are same but the amount of disintegrant was decreased from $30+$ to $20+$, and HPC was removed from the formula and those are compensated by increasing the amount of diluent. The seal coat was given up to a weight build-up of $4 \%$ w/w using 50:50 of ethyl cellulose: water insoluble polymer and on that $15 \% \mathrm{w} / \mathrm{w}$ of the enteric coating was given.

F4: In formulation F4 the core is same as that of F3 and the composition of seal coating is also same but the seal coating is given up to a weight build-up of $6 \% \mathrm{w} / \mathrm{w}$ and on that $15 \% \mathrm{w} / \mathrm{w}$ of the enteric coating was given.

F5: In formulation F5, the the amounts of API, stabilizer, lubricant are the same but the amount of disintegrant was increased to $40+$ and also 5.0 mg/unit of HPC was added, and these amounts were compensated by taking less amount of diluent the seal coat was given up to a weight build-up of $4 \% \mathrm{w} / \mathrm{w}$ using 50:50 of ethyl cellulose: water insoluble polymer and on that $15 \% \mathrm{w} / \mathrm{w}$ of enteric coating was given.

F6: In formulation F6 the core is same as that of F5 and the composition of seal coating is also same but the seal coating is given up to a weight build-up of $6 \% \mathrm{w} / \mathrm{w}$ and on that $15 \% \mathrm{w} / \mathrm{w}$ of the enteric coating was given.

F7: In formulation $\mathrm{F} 7$, the amounts of API, stabilizer, lubricant are same but the amount of disintegrant was decreased from $40+$ to $20+$ and 5.0 $\mathrm{mg}$ /unit of HPC was used, and the decrease in weight was compensated by an increasing amount of diluent. The seal coat was given up to a weight build-up of 4\%w/w using 50:50 of Ethylcellulose: Water insoluble polymer and on that $15 \% \mathrm{w} / \mathrm{w}$ of the enteric coating was given

F8: In formulation F8 the core is same as that of F7 and the composition of seal coating is also same but the seal coating is given up to a weight build-up of $6 \% \mathrm{w} / \mathrm{w}$ and on that $15 \% \mathrm{w} / \mathrm{w}$ of the enteric coating was given.

F9: In formulation $\mathrm{F} 9$, then amounts of API, stabilizer, lubricant are same, but the amount of disintegrant used is $30+\mathrm{mg} / \mathrm{unit}$, and the amount of HPC was decreased to $2.5 \mathrm{mg} / \mathrm{unit}$, and the weight was compensated by increasing amount of diluent. 
The seal coat was given up to a weight build-up of $4 \%$ w/w using 50:50 of ethyl cellulose: water insoluble polymer and on that seal coating $15 \%$ w/w of the enteric coating was given.

F10: In formulation F10 the core is same as that of F9 and the composition of seal coating is also same but the seal coating is given up to a weight build-up of $6 \% \mathrm{w} / \mathrm{w}$, and on that seal coating $15 \% \mathrm{w} / \mathrm{w}$ of the enteric coating was given.

F11: In formulation F11, the amounts of API, stabilizer, lubricant are same, but the number of disintegrants used is $40+\mathrm{mg} / \mathrm{unit}$, and the HPC was removed from the formula, and the weight was compensated by diluent. The seal coat was given up to a weight build-up of $4 \%$ w/w using 50:50 of ethyl cellulose: water insoluble polymer and on that seal coating, $15 \% \mathrm{w} / \mathrm{w}$ of the enteric coating was given.

F12: In formulation F12 the core is same as that of F11 and the composition of seal coating is also same but the seal coating is given up to a weight build-up of $6 \% \mathrm{w} / \mathrm{w}$, and on that seal coating, $15 \% \mathrm{w} / \mathrm{w}$ of the enteric coating was given.

Paliperidone Delayed - Release Tablets: Paliperidone delayed-release tablets were prepared by direct compression technique using different excipients as well as with varying concentrations of polymer proportions using HPMC Phthalate $55 \mathrm{~S}$ as an enteric coating material.

\section{Manufacturing Process: ${ }^{31-34}$}

- Co-shift Paliperidone, sodium carbonate anhydrous, and Crospovidone through sieve \# 30 .

- Shift microcrystalline cellulose through sieve \# 30 .

- Shift the Step 1 and Step 2 materials through \# 30 meshes.

- Load the step 3 materials into a blender and mix for $30 \mathrm{~min}$.

- Shift sodium stearyl fumarate through sieve \# 40 along with a portion of prelubricated blend.

- Load the step 5 material to the blender and mix for $5 \mathrm{~min}$.
- Compress the lubricated blend of step no. 6 into tablets.

- Disperse ethyl cellulose in dehydrated ethanol under stirring to prepare a clear solution to add Water insoluble polymer and stir well.

- Divide the core tablets of step no. 7 into 2 equal lots and coat tablets in a coating machine with step no. 8 dispersion to achieve a target weight gain of $4.0 \pm 0.5 \% \mathrm{w} / \mathrm{w}$ and $6.0 \pm 0.5 \%$ w/w each.

- Warm the Seal-coated tablets in coating pan at $50^{\circ} \mathrm{C} \pm 5^{\circ} \mathrm{C}$ for $20-30 \mathrm{~min}$.

- Disperse hydroxypropyl methylcellulose (HPMC K 100M) in a mixture of dehydrated ethanol and purified water (80:20) under stirring to prepare a clear solution.

- Add diacetylated monoglycerides to the step no. 11 solution.

- Prepare dispersion of pigment blend yellow with purified water using homogenizer and add to the step no. 12 solution and stir well.

- Coat the seal coated tablets of step no. 10 (4\% $\mathrm{w} / \mathrm{w}$ and $6 \% \mathrm{w} / \mathrm{w})$ in a coating machine with step no. 13 dispersion to achieve a target weight gain of $10.0 \pm 0.5 \% \mathrm{w} / \mathrm{w}$.

- Warm the enteric-coated tablets in coating pan at $50^{\circ} \mathrm{C} \pm 5^{\circ} \mathrm{C}$ for $20-30 \mathrm{~min}$.

Tooling: $7.50 \mathrm{~mm}$ round shaped, deep concave plain tooling with corresponding dies.

\section{Tablet Compression Parameters: ${ }^{34-35}$}

Weight of the tablet $150 \mathrm{mg}$

Hardness range 6-10 kP

Thickness range $\quad 4.4 \pm 0.3 \mathrm{~mm}$

There are various in process control parameters should be performed. They are

\section{A) During Tablet Compression:}
$\checkmark$ Appearance
$\checkmark$ Average weight
$\checkmark$ Weight uniformity
$\checkmark$ Hardness
$\checkmark$ Thickness
$\checkmark$ Disintegration time 
B) During Film Coating:

- Appearance

- The average weight of film coated tablets

- Disintegration time
C) During Enteric Coating:

- Appearance

- The average weight of enteric coated tablets

- Acid resistance
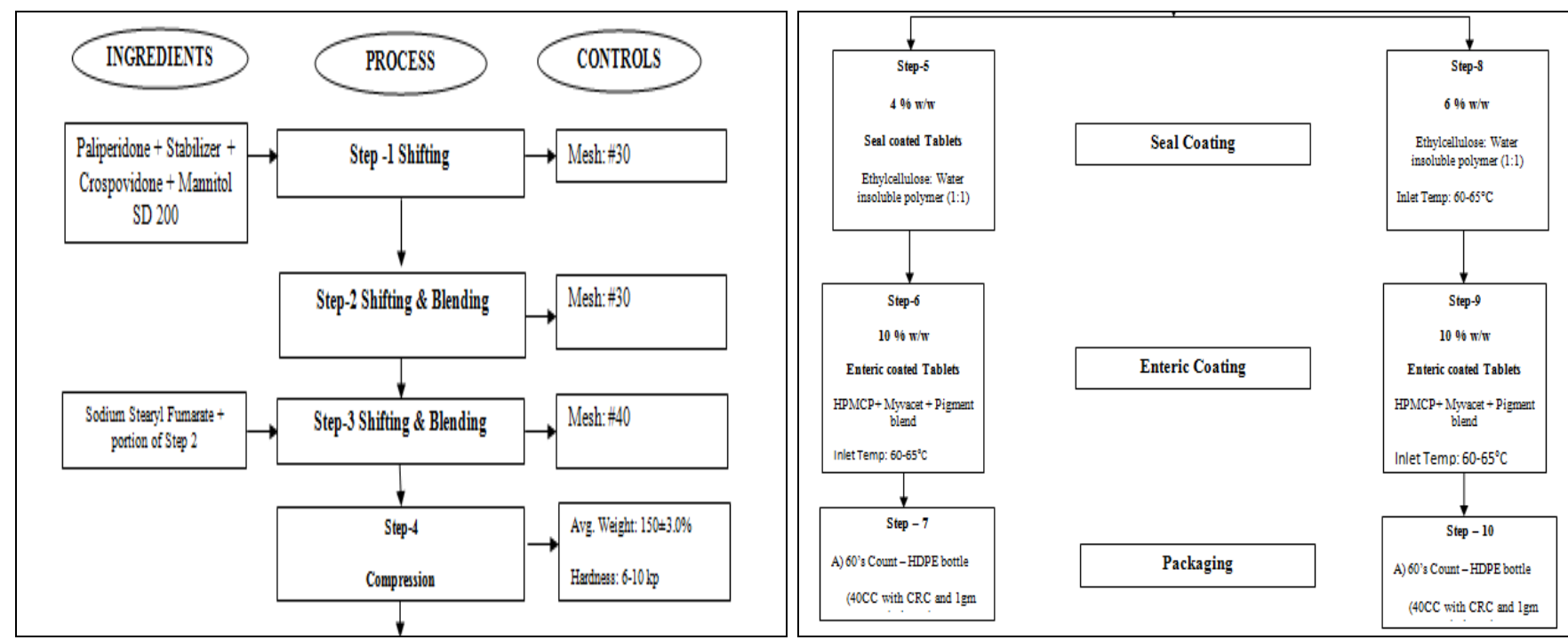

FIG. 1: MANUFACTURING FLOW CHART FOR DELAYED-RELEASE TABLETS

Paliperidone delayed-release tablets were prepared by dry granulation method. The process was displayed in the flow chart.

RESULTS: The present study was undertaken to formulate Paliperidone enteric coated tablets. The study involves preformulation studies of drug and excipients, formulation and processing development along with an evaluation of tablets made with the optimized formulation. Finally, delayed-release tablets were evaluated by in vitro methods. Results and discussion of the above studies are presented below:

TABLE 7: PREFORMULATION STUDIES

\begin{tabular}{|c|c|c|}
\hline S. no. & Characteristics & Results \\
\hline 1 & Organoleptic Evaluation & White to slightly yellowish-white solid \\
\hline 2 & Solubility Analysis & $\begin{array}{l}\text { Very soluble in water, Very soluble in methanol, Freely } \\
\text { soluble in ethanol, chloroform, and ethyl acetate, insoluble } \\
\text { in ether and n-hexane. }\end{array}$ \\
\hline 3 & Bulk density & $0.5214 \mathrm{gm} / \mathrm{ml}$ \\
\hline 4 & Tap density & $0.7684 \mathrm{gm} / \mathrm{ml}$ \\
\hline 5 & Compressibility index & $32.14 \%$ \\
\hline 6 & Hausner's ratio & 01.473 \\
\hline 7 & Melting point & $\begin{array}{l}\text { Because of the gradual degradation of Paliperidone during } \\
\text { heating, the melting point cannot be determined. }\end{array}$ \\
\hline 8 & Molecular weight & 381.43 \\
\hline
\end{tabular}

TABLE: 8 SIEVE ANALYSIS

\begin{tabular}{cccccc}
\hline $\begin{array}{c}\text { Sieve } \\
\text { no }\end{array}$ & $\begin{array}{c}\text { Empty sieve } \\
(\mathbf{g m})\end{array}$ & $\begin{array}{c}\text { Sample } \\
\text { sieve(gm) }\end{array}$ & $\begin{array}{c}\text { Difference } \\
(\mathbf{g m})\end{array}$ & $\begin{array}{c}\text { \% } \\
\text { Retained }\end{array}$ & $\begin{array}{c}\text { \%Cumulative } \\
\text { Retained }\end{array}$ \\
\hline$\# 20$ & 321.4 & 321.4 & 0 & 0 & 0 \\
$\# 30$ & 328.6 & 328.8 & 0.2 & 0.2 & 0.2 \\
$\# 40$ & 299.0 & 300.0 & 1.0 & 1.0 & 1.2 \\
$\# 60$ & 287.2 & 297.4 & 10.2 & 10.2 & 31.4 \\
$\# 100$ & 255.0 & 275.0 & 20.0 & 20.0 & 56.4 \\
$\# 120$ & 274.0 & 299.0 & 25.0 & 25.0 & 89.6 \\
$\# 200$ & 270.0 & 303.2 & 33.2 & 33.2 & 99.8 \\
Receiver & 348.8 & 359.0 & 10.2 & 10.2 & \\
\hline
\end{tabular}

Weight of sample $=100 \mathrm{gm}$ 
TABLE 9: BLEND PROPERTIES OF DIFFERENT FORMULATIONS

\begin{tabular}{cccccc}
\hline Formulation & \multicolumn{5}{c}{ Blend Property } \\
\cline { 2 - 6 } & B.D $(\mathbf{g m} / \mathbf{m l})$ & T.D $(\mathbf{g m} / \mathbf{m l})$ & C.I $(\%)$ & H.R & Property \\
\hline F1 & 0.710 & 0.873 & 19.714 & 1.251 & fair \\
F2 & 0.710 & 0.873 & 19.714 & 1.251 & fair \\
F3 & 0.483 & 0.681 & 29.03 & 1.409 & passable \\
F4 & 0.483 & 0.681 & 29.03 & 1.409 & passable \\
F5 & 0.461 & 0.714 & 35.385 & 1.548 & fair \\
F6 & 0.461 & 0.714 & 35.385 & 1.548 & fair \\
F7 & 0.500 & 0.600 & 23.22 & 1.295 & passable \\
F8 & 0.500 & 0.600 & 23.22 & 1.295 & passable \\
F9 & 0.541 & 0.691 & 21.62 & 1.276 & passable \\
F10 & 0.541 & 0.691 & 21.62 & 1.276 & passable \\
F11 & 0.501 & 0.605 & 17.19 & 1.207 & fair \\
F12 & 0.501 & 0.605 & 17.19 & 1.207 & fair \\
\hline
\end{tabular}

Through this sieve analysis, we came to know that as large quantity of powder was retained on sieve no. 200 , which indicates the poor flow of the drug. Flow property and particle size are inversely proportional to each other as Paliperidone has fine grade of particles; it has poor flow.

\section{Compatability Studies:}

Drug-Excipient Compatibility Studies: The compatibility of drug and formulation components is important prerequisite before formulation. It is, therefore, necessary to confirm that the drug does not react with the polymers and excipients under experimental conditions and affect the shelf life of the product or any other unwanted effects on the formulation.
Procedure: The drug is mixed with excipients in a different ratio. These mixtures were kept in a $5 \mathrm{ml}$ glass white colored vials and packed properly. These vials are exposed to 1) room temperature 2) $2-8{ }^{\circ} \mathrm{C}$ and 3) $40{ }^{\circ} \mathrm{C} / 75 \% \mathrm{RH} .15 \mathrm{gm}$ of the blend is prepared, which is filled in 3 vials. Observations for physical appearance are made at zero weeks, 2 week, and 4 week, the samples were withdrawn for analysis of the following parameter:

1. Moisture content

2. Assay

3. Related substance

4. Appearance.

TABLE 10: RESULTS OF COMPATIBILITY STUDY

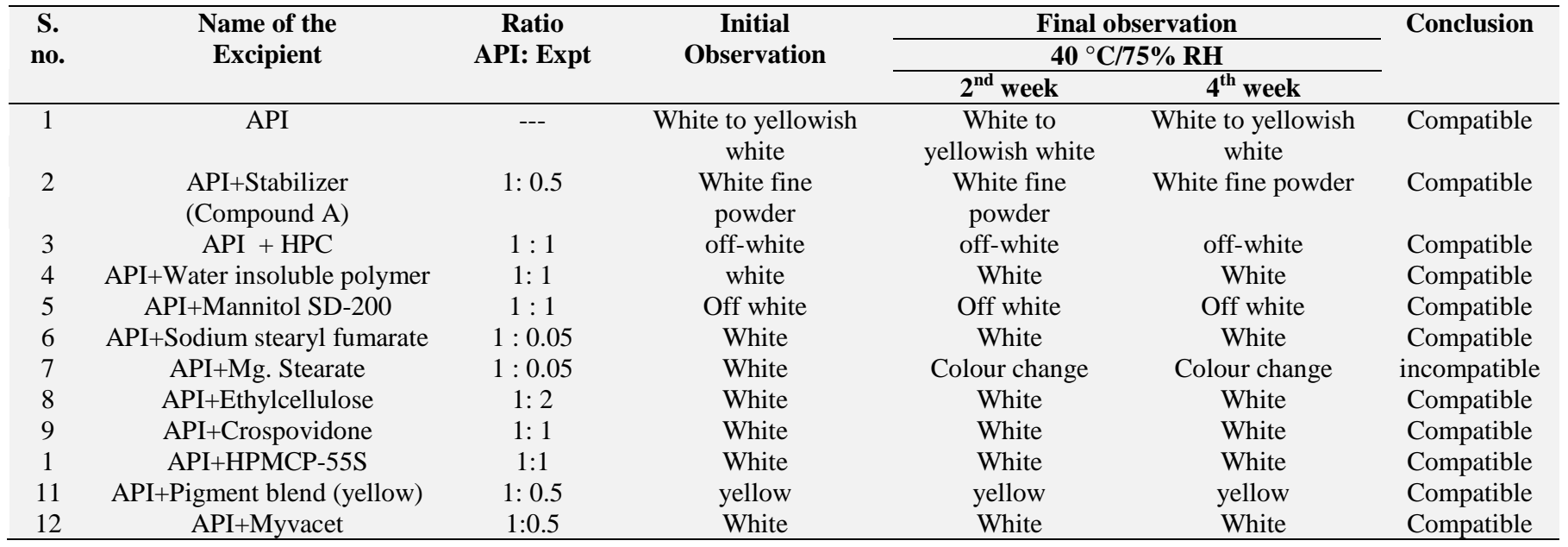

FTIR STUDY: The FT- IR Spectrum of pure Paliperidone drug was compared with that of the physical mixture of Paliperidone and HPMCK 100M. There was no appearance or disappearance of any characteristics peaks. This shows that there is no chemical interaction between the drug and the polymers used in the tablets. The presence of peaks at the expected range confirms that the materials taken for the study are genuine. 


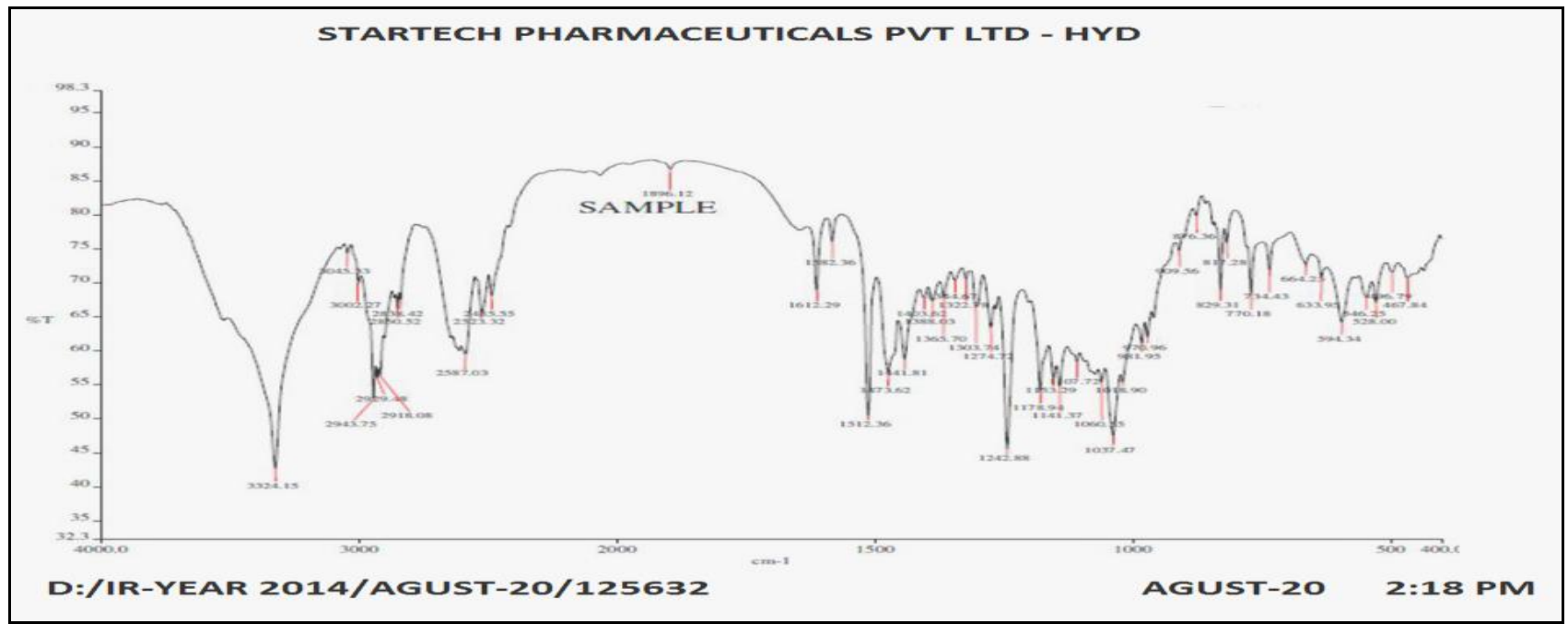

FIG. 2: IR SPECTRUM OF PALIPERIDONE WITH HPMC K100M AND MCC

Standard Calibration Curve of Paliperidone: Standard curve of Paliperidone was determined by plotting absorbance (nm) versus concentration $(\mu \mathrm{g} / \mathrm{ml})$ at $276 \mathrm{~nm}$. The results obtained are as follows: -

TABLE 11: STANDARD CURVE OF PALIPERIDONE

\begin{tabular}{cc}
\hline Conc. in $\boldsymbol{\mu g}$ & Absorbance at 276nm \\
\hline 0 & 0 \\
2 & 0.119 \\
4 & 0.245 \\
6 & 0.367 \\
8 & 0.488 \\
10 & 0.603 \\
\hline
\end{tabular}

The linear regression analysis was done on absorbance data points. A straight-line equation was generated to facilitate the calculation of the amount of drug. The equation is as follows.

$$
(\mathrm{Y}=\mathrm{mx}+\mathrm{c})
$$

Where, $\mathrm{Y}=$ Absorbance, $\mathrm{m}=$ slope, $\mathrm{x}=$ Concentration, $\mathrm{c}=$ Intercept.

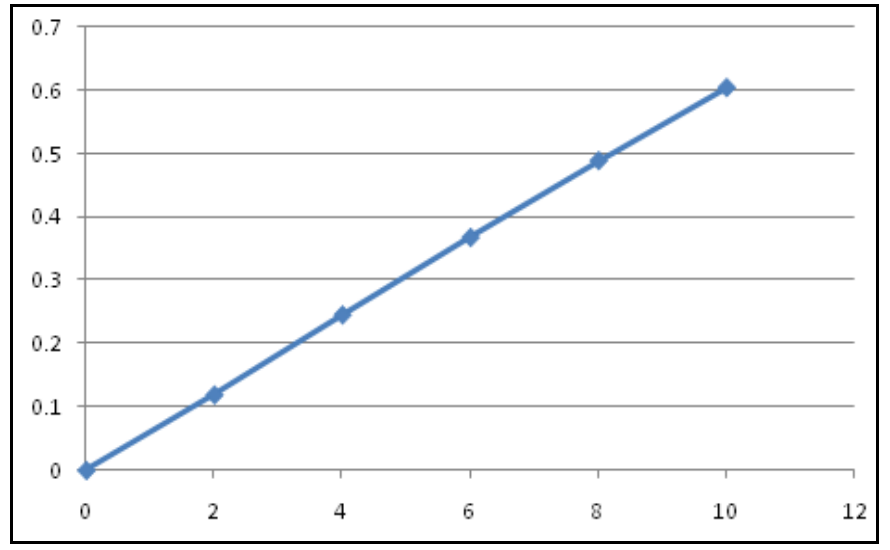

FIG. 3: STANDARD CURVE OF PALIPERIDONE

\section{Evaluation Studies:}

TABLE12: PHYSICAL EVALUATION (CORE TABLET)

\begin{tabular}{cccccccccccccc}
\hline S. no. & Physical parameter & F 1 & F 2 & F 3 & F 4 & F 5 & F 6 & F 7 & F 8 & F 9 & F 10 & F 11 & F 12 \\
\hline 1 & Weight variation & 1.65 & 1.57 & 1.42 & 1.54 & 1.18 & 1.35 & 1.44 & 1.23 & 1.48 & 1.54 & 1.63 & 1.38 \\
2 & Hardness (kP) & 7.8 & 7.4 & 7.2 & 7.4 & 7.1 & 6.8 & 7.4 & 7.8 & 7.5 & 7.8 & 8.0 & 7.6 \\
3 & Thickness (mm) & 3.97 & 3.99 & 3.97 & 3.99 & 3.97 & 3.95 & 3.99 & 3.94 & 4.00 & 3.98 & 3.92 & 3.94 \\
4 & Friability \% & 0.45 & 0.52 & 0.21 & 0.18 & 0.38 & 0.57 & 0.46 & 0.48 & 0.55 & 0.49 & 0.42 & 0.48 \\
5 & Disintegration & $2 \mathrm{~min}$ & $2 \mathrm{~min}$ & $1 \mathrm{~min}$ & $1 \mathrm{~min}$ & $3 \mathrm{~min}$ & $3 \mathrm{~min}$ & $2 \mathrm{~min}$ & $2 \mathrm{~min}$ & $2 \mathrm{~min}$ & $2 \mathrm{~min}$ & $2 \mathrm{~min}$ & $2 \mathrm{~min}$ \\
& time & $44 \mathrm{sec}$ & $50 \mathrm{sec}$ & $50 \mathrm{sec}$ & $44 \mathrm{sec}$ & $10 \mathrm{sec}$ & $18 \mathrm{sec}$ & $50 \mathrm{sec}$ & $44 \mathrm{sec}$ & $15 \mathrm{sec}$ & $22 \mathrm{sec}$ & & $10 \mathrm{sec}$ \\
\hline
\end{tabular}

TABLE 13: PHYSICAL EVALUATION (AFTER SUB COATING AND ENTERIC COATING)

\begin{tabular}{|c|c|c|c|c|c|c|c|c|c|c|c|c|c|}
\hline S. no. & Physical parameter & F 1 & F 2 & F 3 & F 4 & F 5 & F 6 & F 7 & F 8 & F 9 & F 10 & F 11 & F 12 \\
\hline 1 & Hardness $(\mathrm{kP})$ & 8.2 & 8.0 & 8.2 & 8.4 & 8.3 & 8.1 & 8.5 & 8.8 & 8.6 & 9.0 & 9.2 & 8.8 \\
\hline 2 & Thickness (mm) & 4.01 & 4.03 & 4.00 & 4.04 & 4.01 & 4.00 & 4.06 & 4.00 & 4.02 & 4.04 & 3.99 & 4.00 \\
\hline 3 & Hardness (kP) & 8.6 & 8.4 & 8.6 & 8.8 & 8.7 & 8.5 & 9.0 & 9.4 & 9.2 & 9.6 & 9.6 & 9.4 \\
\hline 4 & Thickness (mm) & 4.05 & 4.07 & 4.04 & 4.08 & 4.05 & 4.04 & 4.10 & 4.04 & 4.06 & 4.08 & 4.04 & 4.05 \\
\hline
\end{tabular}

\section{TABLE 14: CHEMICAL EVALUATION}

\begin{tabular}{|c|c|c|c|c|c|c|c|c|c|c|c|c|c|}
\hline S. no. & Parameters & F 1 & F 2 & F 3 & F 4 & F 5 & F 6 & F 7 & F 8 & F 9 & F 10 & F 11 & F 12 \\
\hline 1 & Acid resistant analysis (NMT $10 \%$ in $2 \mathrm{~h}$ ) & 1.38 & 1.36 & 1.48 & 1.78 & 1.82 & 1.69 & 1.80 & 1.86 & 1.84 & 1.90 & 1.90 & 1.28 \\
\hline 2 & Assay $(90-110 \%)$ & 91.8 & 91.5 & 93.4 & 96 & 95.1 & 98.5 & 99 & 97.3 & 98.1 & 96.1 & 99.3 & 99.72 \\
\hline 3 & $\begin{array}{c}\text { Dissolution study (NLT } 75 \% \text { in } 30 \mathrm{~min} \text { in } \\
\text { buffer stage) }\end{array}$ & 97 & 98 & 98 & 96 & 83 & 87 & 94 & 91 & 97 & 97 & 84 & 97 \\
\hline
\end{tabular}



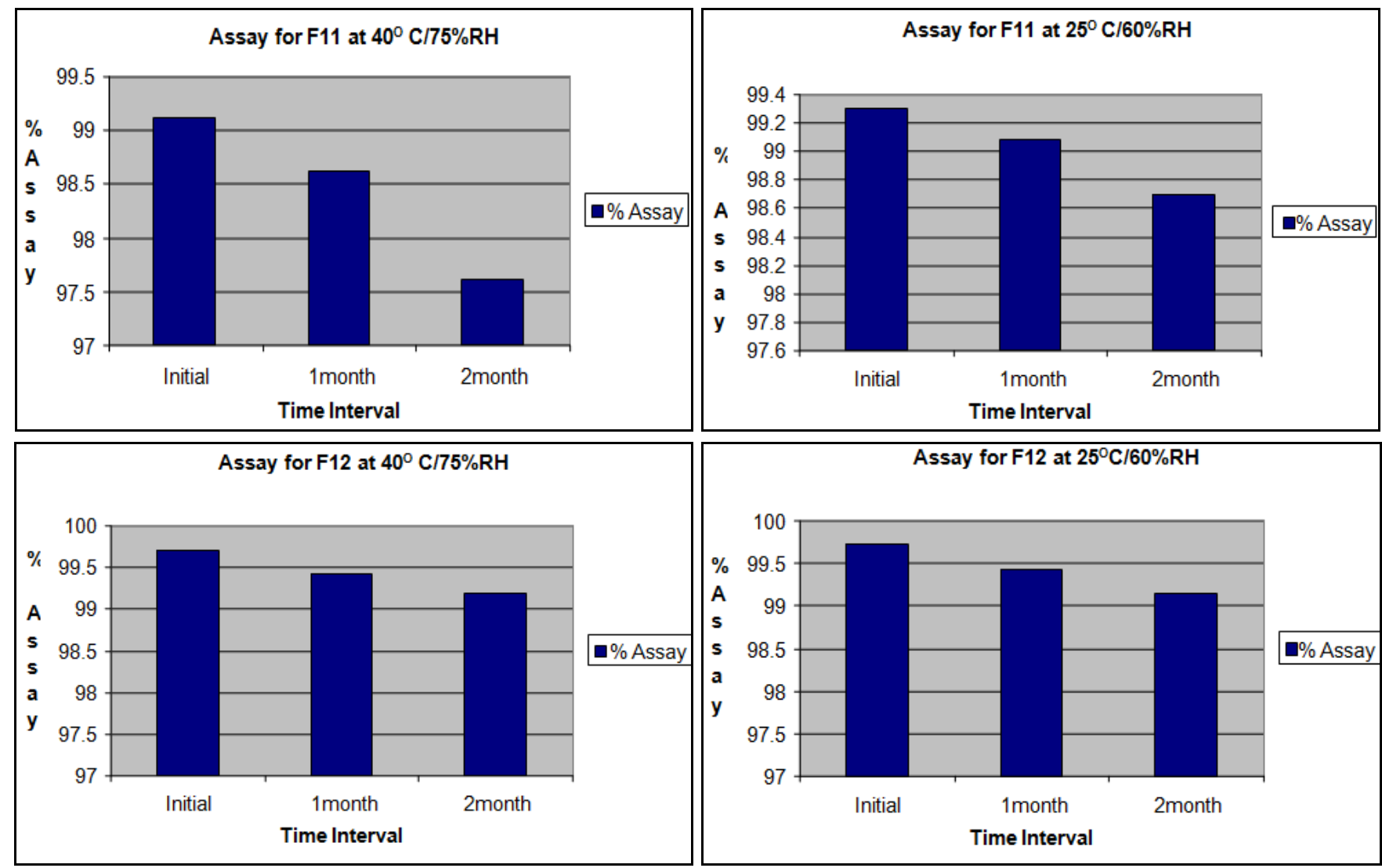

FIG. 4: ASSAY STUDY OF F11-F12
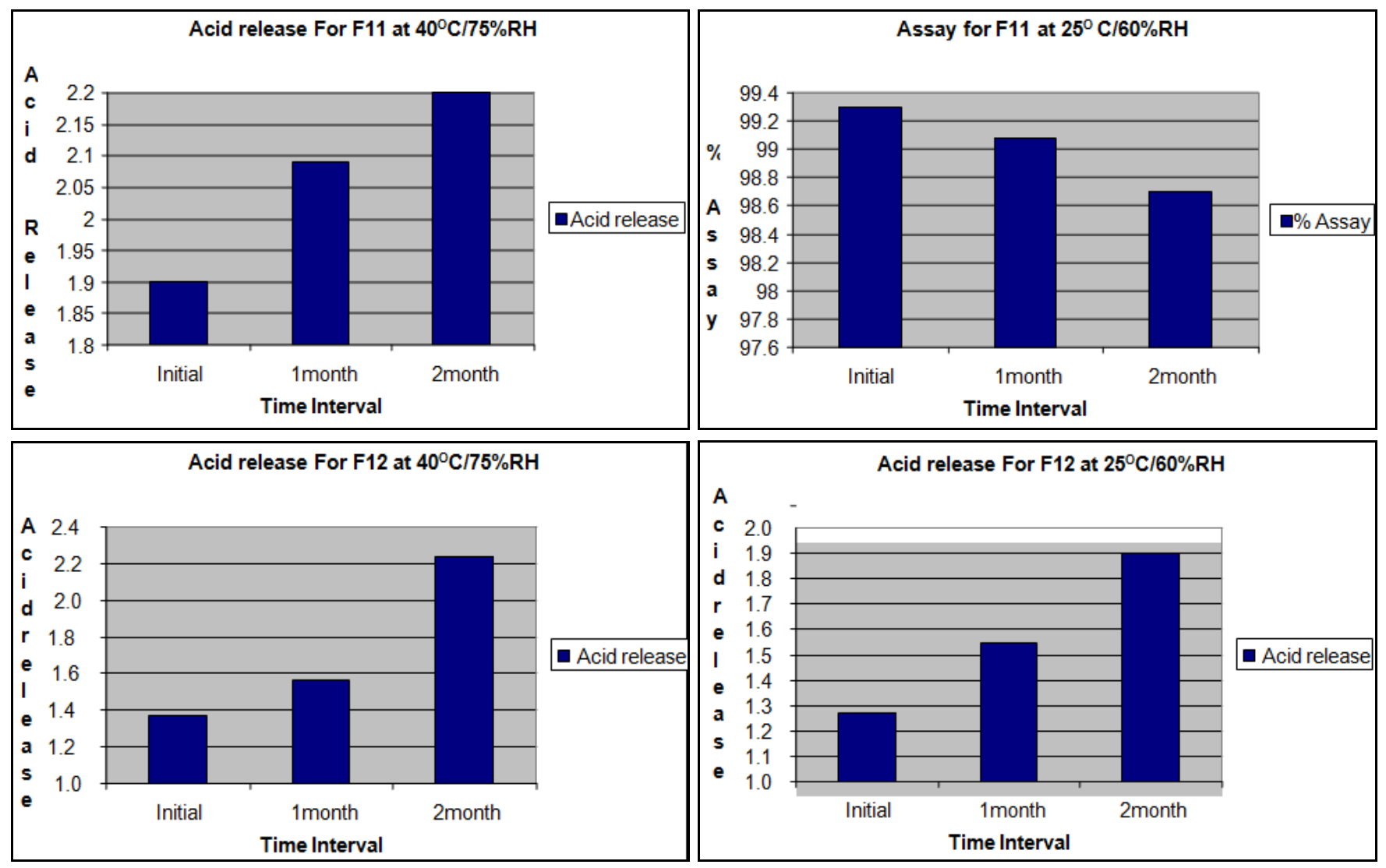

FIG. 5: ACID RELEASE STUDY OF F11-F12

Acid Release: This indicates that the dosage form is resistance to acid media after $2 \mathrm{~h}$. In formulation
11 the acid release of the drug from tablets was found to be $1.90 \%$ initially, after 1 month it raises 
to $2.09 \%$ and $2.04 \%$, later it was found to be 2.20 and $2.12 \%$ after 2 months at $40{ }^{\circ} \mathrm{C} / 75 \% \mathrm{RH}$ and 25 ${ }^{\circ} \mathrm{C} / 75 \% \mathrm{RH}$ respectively. This indicates that there is little change in the acid resistance of Paliperidone delayed-release tablets for batch 11 .

In formulation 12 the acid release of the drug from tablets was found to be $1.28 \%$ initially, after 1 month it raises to $1.54 \%$ and $1.32 \%$, later it was found to be $2.26 \%$ and $2.00 \%$ after 2 months at 40 ${ }^{\circ} \mathrm{C} / 75 \% \mathrm{RH}$ and $25{ }^{\circ} \mathrm{C} / 75 \% \mathrm{RH}$ respectively. This indicates that there is little change in the acid resistance of Paliperidone delayed-release tablets for batch 12 .

Dissolution Studies: The dissolution was carried out for different experimental trials and also for the innovator. The various results that are obtained are tabulated below. Dissolution studies are carried out in the following Media.

Acidic Stage: (pH 1.2)

Medium : $0.1 \mathrm{~N} \mathrm{HCl}$

Type of apparatus : USP - II (paddle type)

RPM : 100

Volume $\quad: 700 \mathrm{ml}$

Temperature $\quad: 37^{\circ} \mathrm{C} \pm 0.5$

Time $: 2 \mathrm{~h}$

Buffer Stage: (pH 8.0)

Medium : $\mathrm{pH} 8.0$ Tris buffer

Type of apparatus : USP - I (paddle type)

RPM : 100

Volume $\quad: 1000 \mathrm{ml}$

Temperature $\quad: 37^{\circ} \mathrm{C} \pm 0.5$

Time : 45 minutes

TABLE 15: DISSOLUTION PROFILE FOR PALIPERIDONE DR TABLETS: (INNOVATOR)

\begin{tabular}{cccccccc}
\hline \multicolumn{7}{c}{ Reference Product- Pariet } \\
\hline Unit & $\mathbf{0}$ & $\mathbf{5}$ & $\mathbf{1 0}$ & $\mathbf{2 0}$ & $\mathbf{3 0}$ & $\mathbf{4 5}$ & $\mathbf{6 0}$ \\
\hline 1 & 0 & 3 & 26 & 96 & 99 & 92 & 90 \\
2 & 0 & 3 & 29 & 95 & 97 & 91 & 90 \\
3 & 0 & 3 & 17 & 76 & 99 & 93 & 91 \\
4 & 0 & 3 & 41 & 97 & 95 & 92 & 87 \\
5 & 0 & 3 & 23 & 97 & 95 & 93 & 90 \\
6 & 0 & 3 & 38 & 96 & 97 & 93 & 91 \\
Average & 0.0 & 3.0 & 29.0 & 92.8 & 97.0 & 92.3 & 89.8 \\
\%RSD & 0 & 0 & 31.4 & 8.9 & 1.8 & 1.9 & 1.6 \\
\hline
\end{tabular}

TABLE 16: DISSOLUTION PROFILE OF FORMULATION 11

\begin{tabular}{cccccc}
\hline & \multicolumn{5}{c}{ \% Drug dissolved in time (min) in Buffer Stage } \\
\hline Unit & $\mathbf{0}$ & $\mathbf{1 0}$ & $\mathbf{2 0}$ & $\mathbf{3 0}$ & $\mathbf{4 5}$ \\
\hline 1 & 0 & 60 & 83 & 81 & 89 \\
2 & 0 & 54 & 85 & 82 & 97 \\
3 & 0 & 52 & 86 & 85 & 92 \\
4 & 0 & 56 & 77 & 86 & 99 \\
5 & 0 & 58 & 83 & 87 & 96 \\
6 & 0 & 62 & 87 & 85 & 97 \\
Average & 0 & 57 & 84 & 84 & 96 \\
\%RSD & 0 & 3.2 & 4.3 & 2.8 & 3.8 \\
\hline
\end{tabular}

TABLE 17: DISSOLUTION PROFILE OF FORMULATION 12

\begin{tabular}{|c|c|c|c|c|c|}
\hline & & \multicolumn{4}{|c|}{ \% Drug dissolved in time (min) in Buffer stage } \\
\hline Unit & $\mathbf{0}$ & 10 & 20 & 30 & 45 \\
\hline 1 & 0 & 27 & 91 & 99 & 88 \\
\hline 2 & 0 & 30 & 93 & 98 & 91 \\
\hline 3 & 0 & 24 & 95 & 94 & 90 \\
\hline Average & 0 & 27 & 93 & 97 & 90 \\
\hline$\%$ RSD & 0 & 2.5 & 2.2 & 1.2 & 1.4 \\
\hline & \multicolumn{5}{|c|}{ Test product- $40^{\circ} \mathrm{C} / 75 \% \mathrm{RH}, 1$ Month } \\
\hline 1 & 0 & 28 & 89 & 94 & 83 \\
\hline 2 & 0 & 22 & 94 & 93 & 89 \\
\hline 3 & 0 & 22 & 87 & 95 & 85 \\
\hline Average & 0 & 24 & 90 & 94 & 87 \\
\hline$\%$ RSD & 0 & 3.4 & 2.6 & 1.1 & 2.8 \\
\hline
\end{tabular}




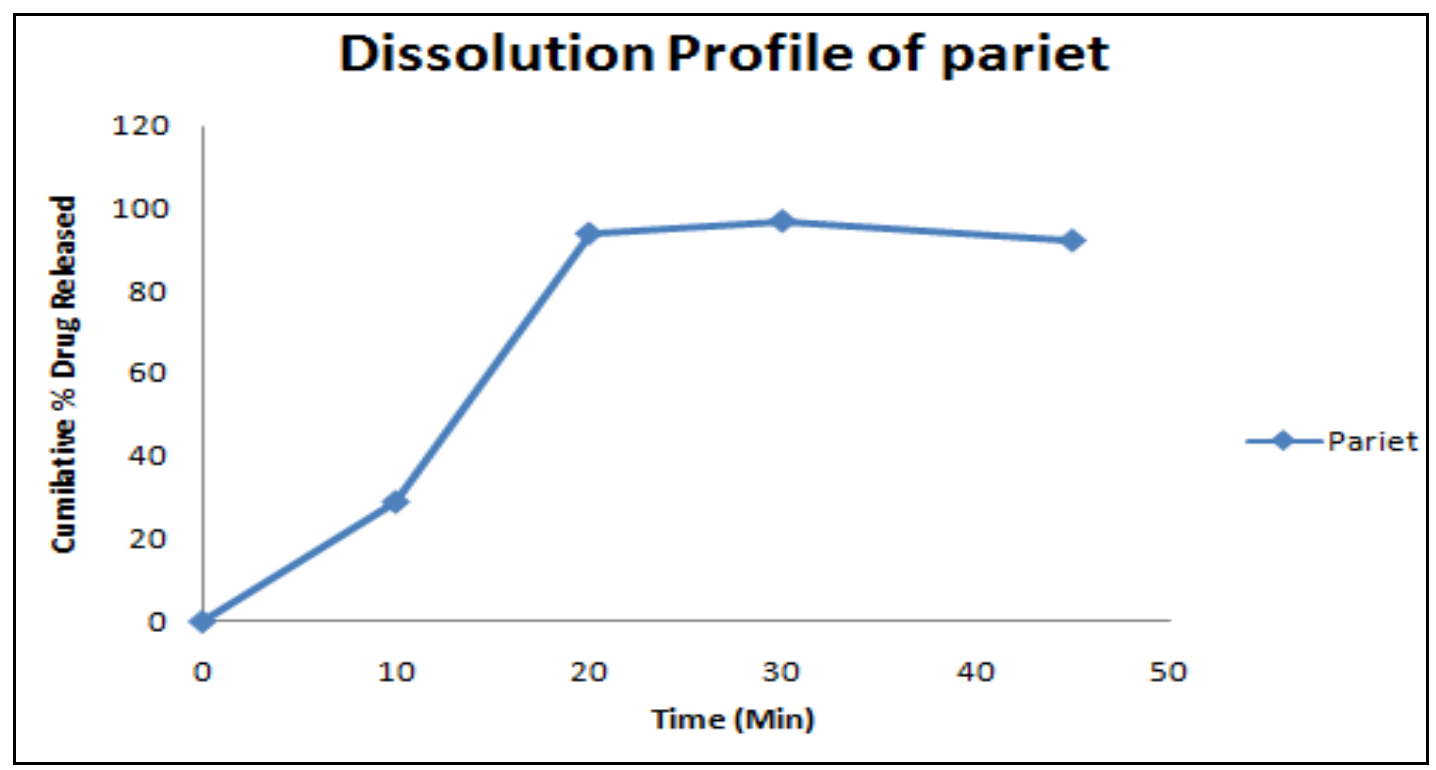

FIG. 6: DISSOLUTION PROFILE FOR PALIPERIDONE DR TABLETS: (INNOVATOR)

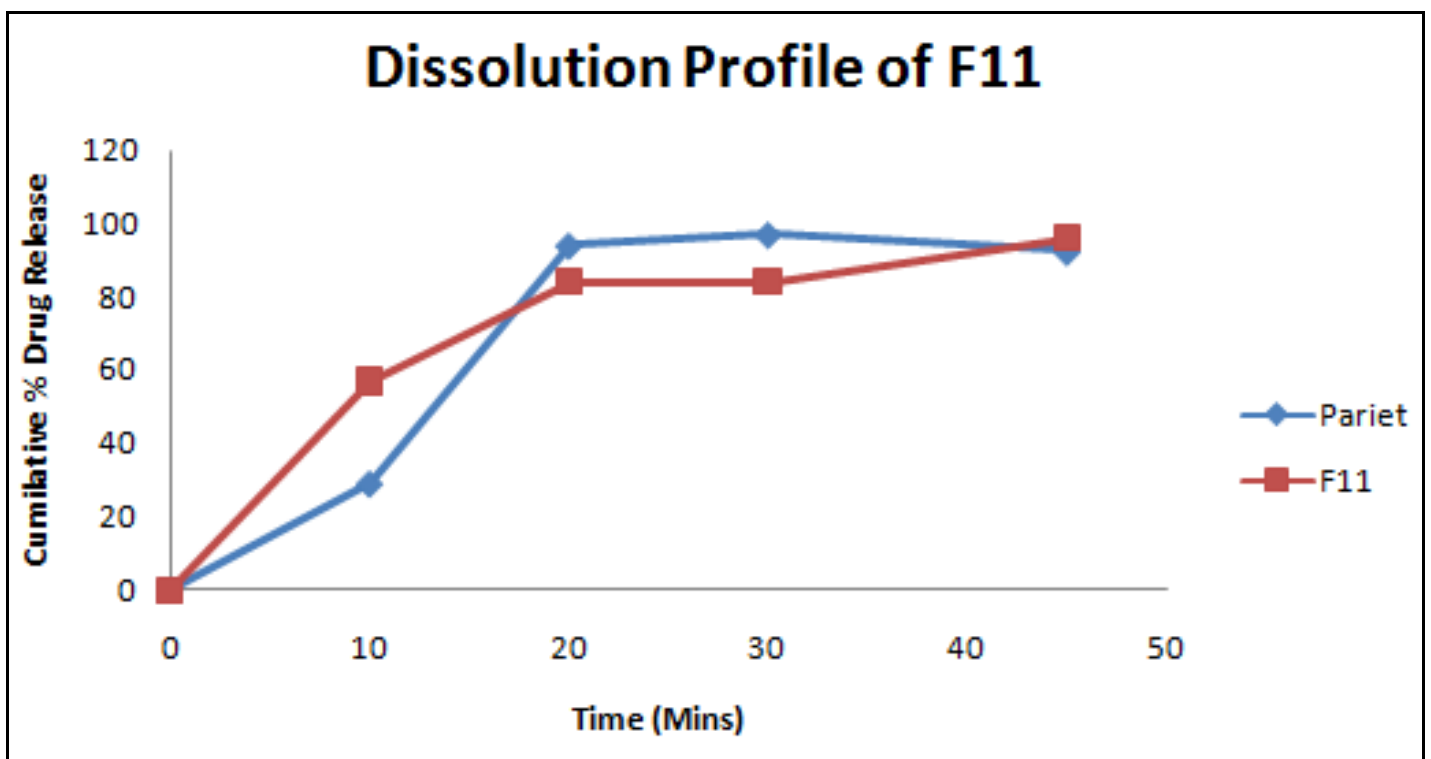

FIG. 7: DISSOLUTION PROFILE OF FORMULATION 11

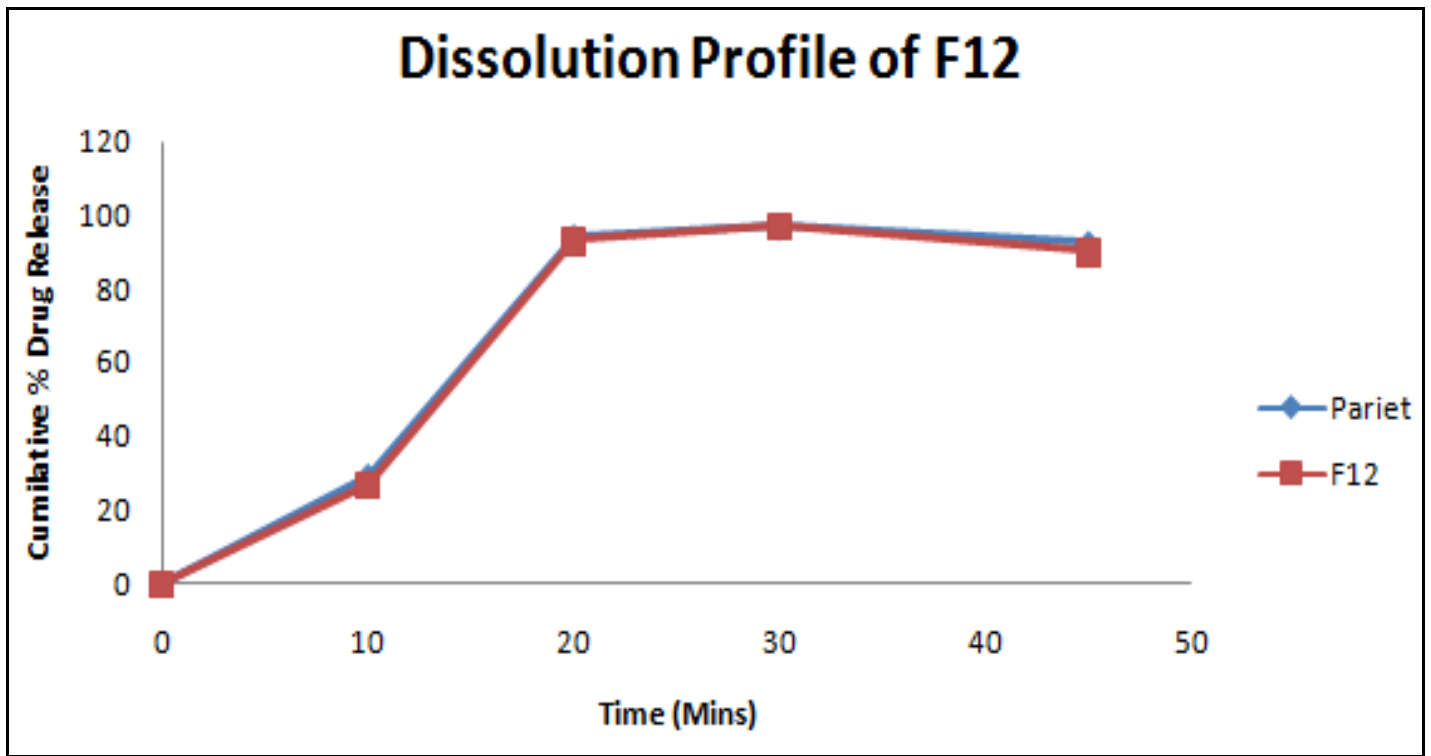

FIG. 8: DISSOLUTION PROFILE OF FORMULATION 12 
TABLE 18: COMPARATIVE DISSOLUTION PROFILE FOR PALIPERIDONE 20MG DR TABLETS (PARIET) AND PREPARED FORMULATIONS F1 TO F6

\begin{tabular}{ccccccccc}
\hline S. no. & Time (min) & F1 & F2 & F3 & F4 & F5 & F6 & Pariet \\
\hline 1 & 0 & 0 & 0 & 0 & 0 & 0 & 0 & 3 \\
2 & 10 & 1 & 0 & 14 & 0 & 1 & 0 & 29 \\
3 & 20 & 96 & 57 & 99 & 64 & 64 & 55 & 94 \\
4 & 30 & 97 & 98 & 98 & 96 & 83 & 87 & 97 \\
5 & 45 & 84 & 85 & 89 & 87 & 98 & 98 & 92.3 \\
\hline
\end{tabular}

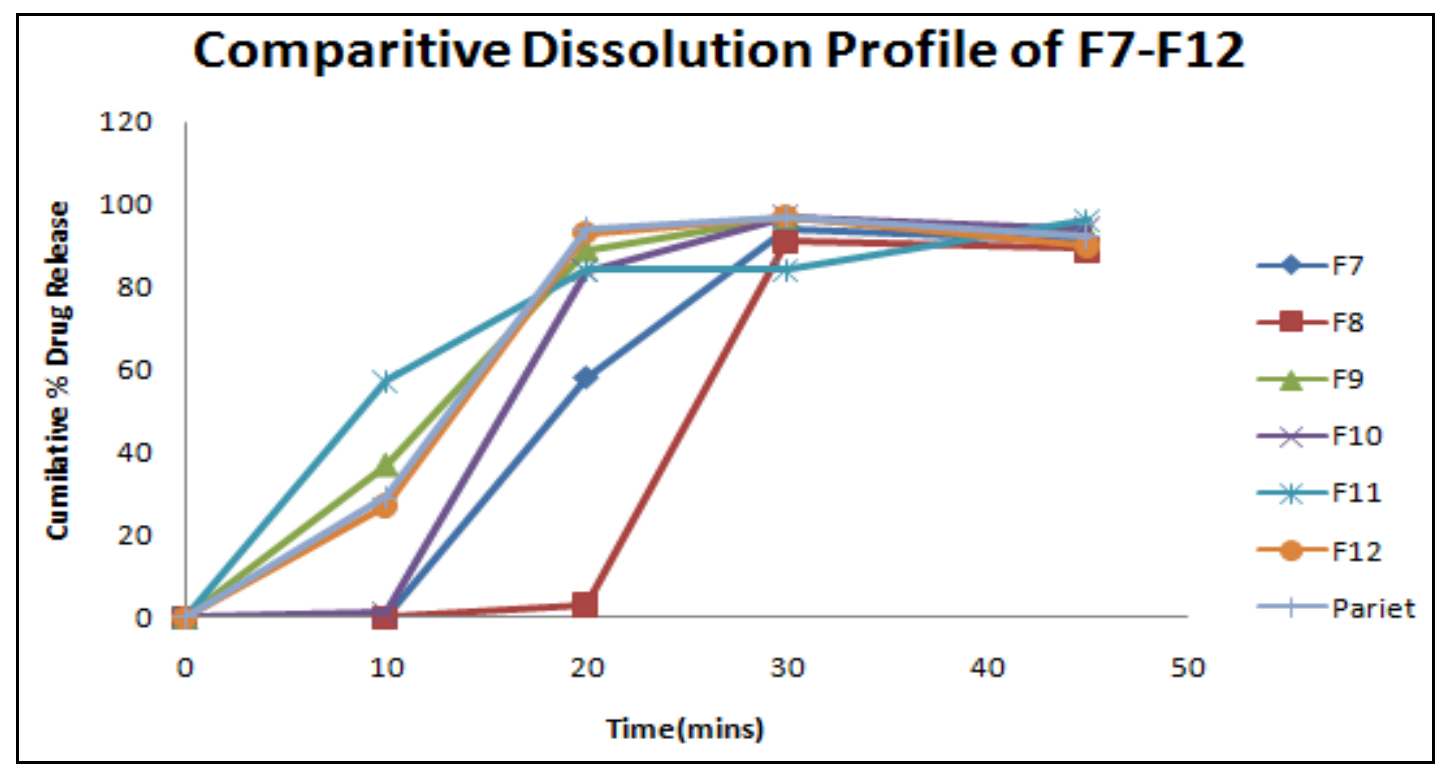

FIG. 9: COMPARATIVE DISSOLUTION PROFILE FOR PALIPERIDONE 20MG DR TABLETS (PARIET) AND PREPARED FORMULATIONS F1 TO F6

\section{Stability Studies:}

TABLE 20: STABILITY DATA FOR F11

\begin{tabular}{ccccc}
\hline $\begin{array}{c}\text { Batch number and } \\
\text { stability condition }\end{array}$ & Description & Assay (\%) & $\begin{array}{c}\text { Acid release in } \\
\mathbf{0 . 1 N} \text { HCl (\%) }\end{array}$ & $\begin{array}{c}\text { Dissolution study in } \\
\text { pH 8.0 buffer }\end{array}$ \\
\hline $\begin{array}{c}\text { Room temperature } \\
(\text { Initial) }\end{array}$ & $\begin{array}{c}\text { Light yellow colored enteric coated } \\
\text { tablets }\end{array}$ & $99.30 \%$ & $1.90 \%$ & $94.38 \%$ \\
$40 \begin{array}{c}{ }^{\circ} \mathrm{C} / 75 \% \mathrm{RH} \\
(1 \mathrm{month})\end{array}$ & $\begin{array}{c}\text { Light yellow colored enteric coated } \\
\text { tablets }\end{array}$ & $98.29 \%$ & $2.09 \%$ & $92.23 \%$ \\
$\begin{array}{c}40{ }^{\circ} \mathrm{C} / 75 \% \mathrm{RH}(2 \\
\text { months) }\end{array}$ & $\begin{array}{c}\text { Light yellow colored enteric coated } \\
\text { tablets }\end{array}$ & $97.3 \%$ & $2.20 \%$ & $92.01 \%$ \\
$25^{\circ} \mathrm{C} / 60 \% \mathrm{RH}$ \\
$\begin{array}{c}(1 \mathrm{month}) \\
25^{\circ} \mathrm{C} / 60 \% \mathrm{RH} \\
(2 \mathrm{months})\end{array}$ & $\begin{array}{c}\text { Light yellow colored enteric coated } \\
\text { tablets }\end{array}$ & $99.05 \%$ & $2.04 \%$ & $93.04 \%$ \\
\hline $\begin{array}{c}\text { Light yellow colored enteric coated } \\
\text { tablets }\end{array}$ & $98.69 \%$ & $2.12 \%$ & $91.36 \%$ \\
\hline
\end{tabular}

\section{TABLE 21: STABILITY DATA FOR F12}

\begin{tabular}{|c|c|c|c|c|}
\hline $\begin{array}{l}\text { Batch number and } \\
\text { stability condition }\end{array}$ & Description & Assay (\%) & $\begin{array}{l}\text { Acid release in } \\
\text { 0.1N HCl }(\%)\end{array}$ & $\begin{array}{l}\text { Dissolution study in } \\
\text { pH } 8.0 \text { buffer }\end{array}$ \\
\hline $\begin{array}{l}\text { Room temperature } \\
\text { (Initial) }\end{array}$ & $\begin{array}{l}\text { Light yellow colored enteric coated } \\
\text { tablets }\end{array}$ & $99.72 \%$ & $1.28 \%$ & $97.38 \%$ \\
\hline $\begin{array}{l}40^{\circ} \mathrm{C} / 75 \% \mathrm{RH} \\
(1 \text { month })\end{array}$ & $\begin{array}{l}\text { Light yellow colored enteric coated } \\
\text { tablets }\end{array}$ & $99.43 \%$ & $1.54 \%$ & $93.23 \%$ \\
\hline $\begin{array}{c}40{ }^{\circ} \mathrm{C} / 75 \% \mathrm{RH} \\
(2 \text { months })\end{array}$ & $\begin{array}{l}\text { Light yellow colored enteric coated } \\
\text { tablets }\end{array}$ & $99.30 \%$ & $2.26 \%$ & $92.14 \%$ \\
\hline $\begin{array}{l}25^{\circ} \mathrm{C} / 60 \% \mathrm{RH} \\
(1 \text { month })\end{array}$ & $\begin{array}{l}\text { Light yellow colored enteric coated } \\
\text { tablets }\end{array}$ & $99.47 \%$ & $1.32 \%$ & $95.98 \%$ \\
\hline $\begin{array}{c}25^{\circ} \mathrm{C} / 60 \% \mathrm{RH} \\
(2 \text { months })\end{array}$ & $\begin{array}{l}\text { Light yellow colored enteric coated } \\
\text { tablets }\end{array}$ & $99.35 \%$ & $2.00 \%$ & $94.92 \%$ \\
\hline
\end{tabular}


Similarity Factor and Dissimilarity Factor Calculation: The similarity factor $\left(\mathrm{f}_{2}\right)$ was defined by CDER, FDA, and EMEA as the "logarithmic reciprocal square root transformation of one plus the mean squared difference in percent dissolved between the test and reference release profiles." Dissimilarity or difference factor $\left(f_{1}\right)$ describes the relative error between two dissolution profiles. It approximates the percent error between the curves. The percent error is zero when the test and reference release profiles are identical and increases proportionally with the dissimilarity between the two profiles.

There are several methods for dissolution profile comparison. $\mathrm{f}_{2}$ is the simplest among those methods. Moore \& Flanner proposed a model independent mathematical approach to compare the dissolution profile using two factors $\mathrm{f}_{1} \& \mathrm{f}_{2}$.

$\mathrm{f}_{1}=\left\{\left[\sum_{\mathrm{t}=1}{ }^{\mathrm{n}}\left|\mathrm{R}_{\mathrm{t}}-\mathrm{T}_{\mathrm{t}}\right|\right] /\left[\sum_{\mathrm{t}=1}{ }^{\mathrm{n}} \mathrm{R}_{\mathrm{t}}\right]\right\} .100$

$f_{2}=50 . \log \left\{\left[1+(1 / n) \sum_{t=1} n\left(R_{t}-T_{t}\right)^{2}\right]^{-0.5} .100\right\}$

Where ' $\mathrm{R}_{\mathrm{t}}$ ' and ' $\mathrm{T}_{\mathrm{t}}$ ' are the cumulative percentage dissolved at each of the selected $\mathrm{n}$ time points of the reference \& test product, respectively. The factor $f_{1}$ is proportional to the average difference between the two profiles, whereas factor $f_{2}$ is inversely proportional to the averaged squared difference between the two profiles, with emphasis on the larger difference among all the time points. The similarity factor $f_{2}$ and its significance is shown in the following table.

TABLE 22: SIMILARITY FACTOR F2 AND ITS SIGNIFICANCE

\begin{tabular}{ccc}
\hline S. No. & Similarity factor $(\mathbf{f} 2)$ & Significance \\
\hline 1. & $<50$ & Test and reference profiles are dissimilar. \\
2. & $50-100$ & Test and reference profiles are similar. \\
3. & 100 & Test and reference profiles are identical. \\
4. & $>100$ & The equation yields a negative value. \\
\hline
\end{tabular}

TABLE 23: F 2 VALUE CALCULATION

\begin{tabular}{cccccc}
\hline \multicolumn{7}{c}{ Dissolution Profile Comparision } \\
\hline Time (mins) & Innovator $(\mathbf{R})$ & F12 $(\mathbf{T})$ & $(\mathbf{R}-\mathbf{T})$ & $(\mathbf{R}-\mathbf{T})^{\mathbf{2}}$ & $\mathbf{f}_{\mathbf{2}}$ value \\
\hline 0 & 0 & 0 & 0 & 0 & \\
10 & 29 & 27 & 2 & 4 & \\
20 & 94 & 93 & 1 & 1 & 89 \\
30 & 97 & 97 & 0 & 0 & 5.29 \\
45 & 92.3 & 90 & 2.3 & 10.29 & \\
Total & 220 & 217 & 3 & & \\
\hline
\end{tabular}

DISCUSSION: The objective of the study is to formulate and evaluate Paliperidone DelayedRelease tablets compared to the innovator product. Twelve formulations of enteric coated tablets of Paliperidone were developed by preparing core tablets using microcrystalline cellulose as diluent and sodium starch glycolate as super disintegrant and stabilizer in different proportions and varying the compositions of sub coating and enteric coating using pigment yellow, myvacet, and HPMC K 100M. The core tablets were prepared by Direct compression method. The results indicated that the finished product formulation F12 fulfilled all the specifications of the physical properties and Invitro release and are comparable to the innovator product. Formulation F1 to F11 was failed due to various reasons like less acid resistance compared to the innovator or increased impurities profiles during stability or less in-vitro drug release compared to the innovator. Even though all the formulations are releasing the drug, but those are not comparable to the innovator product.

Formulation F12 fulfilled all the specifications prescribed for Paliperidone delayed-release tablets and comparable to the innovator product ${ }^{36-39}$. 
SUMMARY AND CONCLUSION: The Paliperidone is a proton pump inhibitor which is used in the treatment of Dopamine Antagonist.

In this study, Paliperidone enteric coated tablets were prepared by using HPMC K $100 \mathrm{M}$ as an enteric coating polymer. Twelve formulations of enteric coated tablets of Paliperidone were developed by preparing core tablets using Microcrystalline cellulose as diluent and Sodium starch glycolate as super disintegrant and Stabilizer as in different proportions and varying the compositions of sub coating and enteric coating using Pigment yellow, Myvacet, and HPMC K 100M.

The core tablets were prepared by Direct compression method. F12 was found to be best of all the formulations showing drug release matching the innovator product so to that formulation all the quality control tests were done for confirmation. Stability study is carried out for 3 months at $25{ }^{\circ} \mathrm{C}$; $60 \% \mathrm{RH}$ : and $40^{\circ} \mathrm{C} ; 75 \% \mathrm{RH}$, according to $\mathrm{ICH}$ guidelines. The tablets were tested for acid release during the stability period and confirmed that results were found within limits. The identified formula shall be utilized for the formulation development and other studies for the successful launching of the product.

\section{ACKNOWLEDGEMENT: Nil}

\section{CONFLICT OF INTEREST: Nil}

\section{REFERENCES:}

1. Chakraborty S, Sarkar S and Debnath SK: Formulation development and evaluation of pantoprazole enteric coated tablets. International Journal of Chem Tech Research 2009; 1(3): 663-666.

2. Bageshwar D: Simultaneous determination of pantoprazole sodium and itopride hydrochloride in pharmaceutical dosage form by first-order derivative UV spectrophotometry, Asian Journal of Pharmaceutical and Clinical Research 2010; 3(3): 221223.
3. Breier AR, Paim CS, Steppe M and Schapoval EE.: Development and validation of dissolution tests for fexofenadine hydrochloride capsules and coated tablets. Journal Pharm Pharm Science 2005; 8(2): 289-98.

4. Reddy P, Battu and Reddy NKK: Development and validation of RP-HPLC for the Pantoprazole Sodium Sesquihydrate in Pharmaceutical dosage forms and Human Plasma 2009; 1(2): 195-198.

5. Kakde RB: Three-wavelength spectrophotometric Method for simultaneous estimation of pantoprazole and domperidone in pharmaceutical preparations. International Journal of Pharma Tech Research 2009; 1(2): 386-389.

6. Raffin RP, Colome LM, Pohlmann AR and Guterres SS: Preparation, characterization, and in-vivo anti-ulcer evaluation of pantoprazole-loaded micro-particles. European Journal of Pharmaceutics and Biopharmaceutics 2006; 63: 198-204.

7. Meyera UA: Interaction of proton pump inhibitors with cytochromes P450 consequences for drug interactions. Yale Journal of Biology and Medicine 1996; 69: 203209.

8. Horn JR and Howden CW: Similarities and differences among delayed release proton-pump inhibitor formulations. Alimentary Pharmacological Therapy 2005; $22: 20-24$

9. Kalaichelvi R: International Journal of Chemistry Research 2010; 1(1).

10. Rajeshwar K: Develop gastro-resistant drug delivery system for pantoprazole. International Journal of Pharmacy and Pharmaceutical Sciences 2010; 2(3).

11. Prasanna Reddy B: determination of pantoprazole sodium and lansoprazole in individual dosage form tablets by RP-HPLC using single mobile phase. 2010; I.

12. Ravi Kumar P, Bhanu Prakash $P$ and Murali Krishna M: Simultaneous estimation of domperidone and pantoprazole in solid dosage form by UV spectrophotometry. E-J Chem 2006; 3(3): 142- 145.

13. Devik Z: The simple visible spectrophotometric method is described for the determination of pantoprazole sodium sesquihydrate. Chemical Industry \& Chemical Engineering Quarterly 2010; 16(1): 97-102. 
14. Ferron GM: Oral bioavailability of pantoprazole suspended in sodium bicarbonate solution. American Journal of Health-System Pharmacy 2003; 60(13): 1324-1329.

15. Ashford M, Fell JT, Attwood D and Woodhead PJ: An in-vitro investigation into the suitability of $\mathrm{pH}$ dependent polymers for colonic targeting. International Journal of Pharmaceutics 1993; 91(2-3): 241-245.

16. Zupan`ǐca V, Ograj`seka N, Kotar-Jordanb B and Vrěcerb F: Physical characterization of pantoprazole sodium hydrates. International Journal of Pharmaceutics 2005; 291: 59-68.

17. Saini V and Gupta VB: Estimation of pantoprazole from multiparticulate dosage form by new HPLC method, International Journal of Pharm Tech Research 2009; 1(4): 1094-1096.

18. Imadomi JM, McIntyre L, Bernard L and Fendrick M: Step-down from multiple to single-dose proton pump inhibitors; a prospective study of patients with heartburn or acid regurgitation completely relieved with PPI. The American Journal of Gastroenterology 2003; 98(9): 1940-1944.

19. Robinson M: Proton pump inhibitors, update on their role in acid-related gastrointestinal diseases. International Journal of Clinical Practice 2005; 59(6): 709-15.

20. Ravi Kumar Reddy J, Gnanaprakash K and Badarinath AV: Formulation and evaluation of microparticles of metronidazole. J Pharm Sci \& Res 2009; 1(x): 131-136.

21. Damodharan N: development and evaluation of delayed release doxycycline tablets. International Journal of Pharmacy and Pharmaceutical Sciences, 2010; 2: 116119.

22. Patel SR: Prepare delayed release i.e., enteric coated tablets of Rabeprazole sodium by using Methacrylic acid copolymer (2010).

23. Fukui E, Miyamura N, Uemura K and Kobayashi M: Preparation of enteric coated timed-release press-coated tablets and evaluation of their function by in-vitro and in-vivo tests for colon targeting, International Journal of Pharmaceutics 2000; 204: 7-15.

24. Crotts G, Sheth A, Twist J and Ghebre-Shellassie I: Development of an enteric coating formulation and process for tablets primarily composed of a highly water soluble, organic acid. European Journal of Pharmaceutics and Biopharmaceutics 2000; 51: 71-76.

25. Gordon MS, Fratis A, Goldblum R, Jung D, Schwartz KE and Chowhan ZT: In-vivo and in-vitro evaluation of four different aqueous polymeric dispersions for producing an enteric coated tablet International Journal of Pharmaceutics 1995; 115(1): 29-34.

26. Tozer TN: Malcolm Rowland. Introduction to Pharmacokinetics an Pharmacodynamics, Edition $3^{\text {rd }}$, 106.

27. Uchegbu IF and Schatzlein AG: Polymers in Drug Delivery. 235.

28. Chein YW: Novel drug delivery systems, Marcel Dekker, Newyork (NY), Edition $2^{\text {nd }}, 1992: 2,36,140$ $141,484$.

29. Ansel HC, Allen LV and Popovich NG: 2000.

30. Ansel's: Pharmaceutical Dosage forms and Drug Delivery Systems, 268.

31. William Andrew, Pharmaceutical Manufacturing Encyclopedia, Edition $3^{\text {rd }}$, Vol. 1.

32. Wise and Donald: Handbook of Pharmaceutical Controlled Release Technolog 2000; 473.

33. Uchegbu IF and Schatzlein AG: Polymers in Drug Delivery: 238.

34. Ansel $\mathrm{CH}$ and Poppovich NG: Pharmaceutical Dosage Forms and Drug Delivery Systems, New Delhi: B. I. Waverly Pvt. Ltd, Edition 6 ${ }^{\text {th }}, 1995: 213$.

35. Schwartz BJ: Pharmaceutical Dosage Forms: Tablets. Marcel Dekker, New York. Drug delivery, 1991-2000: 75-130. Available from: URL: www. wikipedia.org

36. Lachman L, Joseph L and Kanig: The Theory and Practice of industrial pharmacy, Lea \& Febiger, Philadelphia, Edition $3^{\text {rd }}, 1986: 331-2,364-8$.

37. Watt PR and Armstrong NA: "Tablet and Capsule Machine Instrumentation".

38. Lachman L, Lieberman HA, Kanig JL: The Theory and Practice of Industrial Pharmacy, Bombay: Varghese, Edition $3^{\text {rd }}, 331-332,364-368$.

39. Mc Ginity JW and Felton LA: Aqueous polymeric coating for pharmaceutical dosage forms, Edition $3^{\text {rd }}$, 327. 
How to cite this article:

Vijendhar G, Swethaa C and Mohini K: Formulation and evaluation of delayed release tablets of Paliperidone. Int J Life Sci \& Rev 2015; 1(2): 48-64. doi: 10.13040/IJPSR.0975-8232.IJLSR.1(2).48-64.

All @ 2015 are reserved by International Journal of Life Sciences and Review. This Journal licensed under a Creative Commons Attribution-NonCommercial-ShareAlike 3.0 Unported License.

This article can be downloaded to ANDROID OS based mobile. Scan QR Code using Code/Bar Scanner from your mobile. (Scanners are available on Google Playstore) 